THE ANNALS OF "DUNAREA DE JOS" UNIVERSITY OF GALATI

FASCICLE XV ISSN - 1454 - 9832 - Vol. 2/2019

Article DOI: https://doi.org/10.35219/efms.2019.2.04

\title{
THE IMPORTANCE OF TECHNICAL ANALYSIS FOR IMPROVING PERFORMANCE IN ATHLETICS IN LONG DISTANCE RUNNING
}

\author{
Andreea-Georgiana DOBRE ${ }^{1}$, Claudiu MEREUȚĂ ${ }^{2}$, Florin-Eduard GRIGORE ${ }^{3}$ \\ ${ }^{1}$ Universitatea Transilvania, Brașov, Facultatea de Educație fizică și Sporturi montane, Romania \\ ${ }^{2}$ Universitatea Dunarea de Jos, Galați, Facultatea de Educație fizică și Sport,Romania \\ ${ }^{3}$ Universitatea Dunarea de Jos, Galați, Facultatea de Educație fizică și Sport,Romania
}

\begin{abstract}
It is well known that the level at which the performances in the sports competitions have come lately is also due to the improvement of the specific techniques by: studying the most intimate / hidden aspects of the running technique that provide insight into the level of influence of the muscle chains involved in each phase of the movement; knowledge of the biomechanical details that can improve the technique of the general run and the departures from the start. It is assumed that participation in high-performance competitions is possible by restructuring the training efforts during the annual training cycle, using increased proportionate efforts in the mixed and anaerobic area as well as the approach as a separate indicator of the compensatory effort, and in this restructuring an essential role could be played by the technical aspect of long runs. When we discuss the technique of athletics, we must consider two aspects which, depending on how well they are improved, influence the final result. This is the sample technique and the treadmill technique.
\end{abstract}

Keywords: performance, athletics, technique, long distance running.

Sports performance represents the area with the highest level of interest in terms of the dynamics of international scientific research in the field of sports. Studies in this direction have enabled researchers to exhibit different approaches.

According to Manno R. (1996, p. 26), training is "a complex intervention process, whose aim is learning and improving the technique, under a simple or chained form, for an individual, a group or a team and aimed at developing physical-psychic abilities allowing achieving maximum sports performance, taking into account the specific characteristics of the subject, group, or team ".

Athletes do not develop overnight, and the coaches can't work miracles. There are no shortcuts, which explains that "adapting to your training is the sum of transformations caused by repeated, systematic exercise." (BOMPA T.O., 2002, p. 18).

The technique is important, primarily through the economy of movements and their effectiveness and as such it should not be understood in isolation, since it is subject to a large extent to the level of development of the conditional and coordination abilities, being closely related to the tactics, psychological, theoretical and artistic training, in the fields of sport that require this (according to Tudor V., 1999, p. 24).

The role of technique in middle-distance and longdistance track running trials has become more and more important and consists in allowing the runners to accomplish effectiveness and ease in movement, which will allow crossing the distance at a higher speed.
In middle-distance track running, the physiological requirements influence the running technique.

The current synthetic track surfacing have imposed a perfected running technique, and the smallest mistakes in the technique can lead to fatigue in the lower limbs muscles.

During the training for perfecting the technique, a tendency to a simple, relaxed running stride, characterized by fewer useless movements that would negatively influence finishing the track in a better time.

The solution to all these "problems" lies, obviously, in monitoring and assessing the technical preparation during training.

The technique is, from my point of view, one that could make the difference in saving energy and effort into optimal effort scaling, by removing unnecessary movements of the head and torso, by correcting the heavy stride in running and by finding the most appropriate ways of removing the imbalances between the upper and lower limbs.

The proposed research programme opens a new perspective in increasing sports performance increase thanks to the theoretical and practical approach of the middle distance and long distance running.

Research in this direction would lead to the clear and undeniable establishment that in middl distance and long distance running, the "key to success" lies not only in the relationship between the motric development endurance and considerable improvement of the effort capacity of each runner, but also in the relationship between the two and an adequate technical training, 
depending on the specific characteristics of individual specificity.

\section{The hypotheses of the research}

It is assumed that taking part in high level competitions is possible through restructuring training efforts throughout the annual preparation cycle, using the efforts from the mixed and anaerobic area to a great extent, as well as approaching the compensating effort as a separate indicator, an essential part in the restructuring being also played by the technical aspect of long distance running.

\section{The purpose of the research}

It consists in continuous refinement and guidance of the training content through reorganizing the preparation during the annual cycle in pursuit of obtaining the level of fitness for the targeted competition.

The theoretical importance consists in devising and arguing the content, methods and preparation means that should contribute to the increase of specific endurance, to maintaining the running speed throughout a large length of the race, by streamlining the running techniques, whereas the results of the research shall contribute to complementing the theoretical background in our field.

The practical importance of the research lies in devising a training and competition pattern, that will allow the specialists to select the most efficient indicators of physical training, as well as the greatest possible means and methods to improve the technique and the specific endurance, the running speed during the race, that will reflect the level of training appropriate to each stage, programmes being applied in this respect to groups of athletes taking part in middle-distance and long-distance track running trials.

The topicality of the theme refers to the deficitary level of technical preparation for the $1500 \mathrm{~m}$. and $3000 \mathrm{~m}$. running trials and the urge for a modern intervention methodology in the training in order to objectively detect and correct the technical errors. We mention that the literature presents less information and conceptual ideas of athletic training to argue and scientifically implement a structure of the approaching process of the athletics techniques researched by us.

The targeted group of the project consists of 5 juniors from the athletics department of the Sports Highschool in Galaţi.

The methods used in achieving the research aims are the following: the study of the literature; the comparative method; the pedagogical and case study experimental method; the pedagogical observation method; the statistical mathematic of data processing and interpretation method; the graphic analysis of research results method; the testing method.

The analysis of the running pace technique with KINOVEA software

Kinovea is a video analysis software that allows capturing and playing, at different speed, of a video recording, with the possibility to analyse the kinematic parametres. Kinovea has been especially created to analyse motion in different sports in order to improve sport performance. (Guzman-Valvidia C.H., 2013; Elwardany S.H., 2015).

When discussing about technique, we need to consider two aspects, which, according to the level of acquisition, may influence the final result. These aspects are the trial technique and the running pace technique.

As a result of the shooting, the technique of the distance runner will be analyzed from the point of view of the joints (hip, knee, ankle ), of the angles and of the 3 phases: the damping phase, the moment of the vertical and the push phase.

In conclusion, depending on these stages of the double trademill, we will also graphically analyze the following aspects:

- the horizontal speed of the three joints studied (ankle, knee, hip);

- the push angle.

- the variation of thigh-calf angle during each phase (damping, vertical moment and push).

\section{Analysis of horizontal velocity variation in the damping phase}

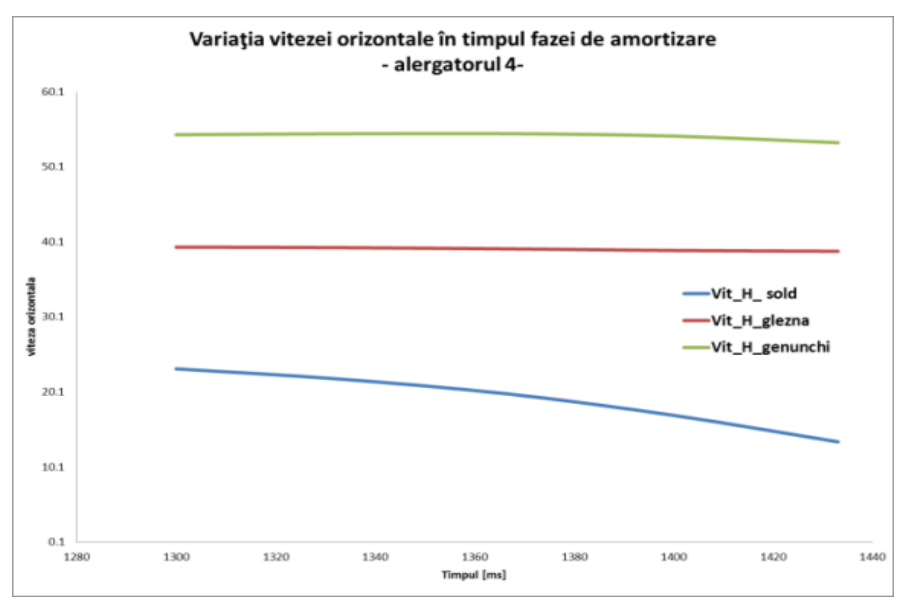

Figure 1 - Variation of horizontal speed during the damping phase for runner 4 


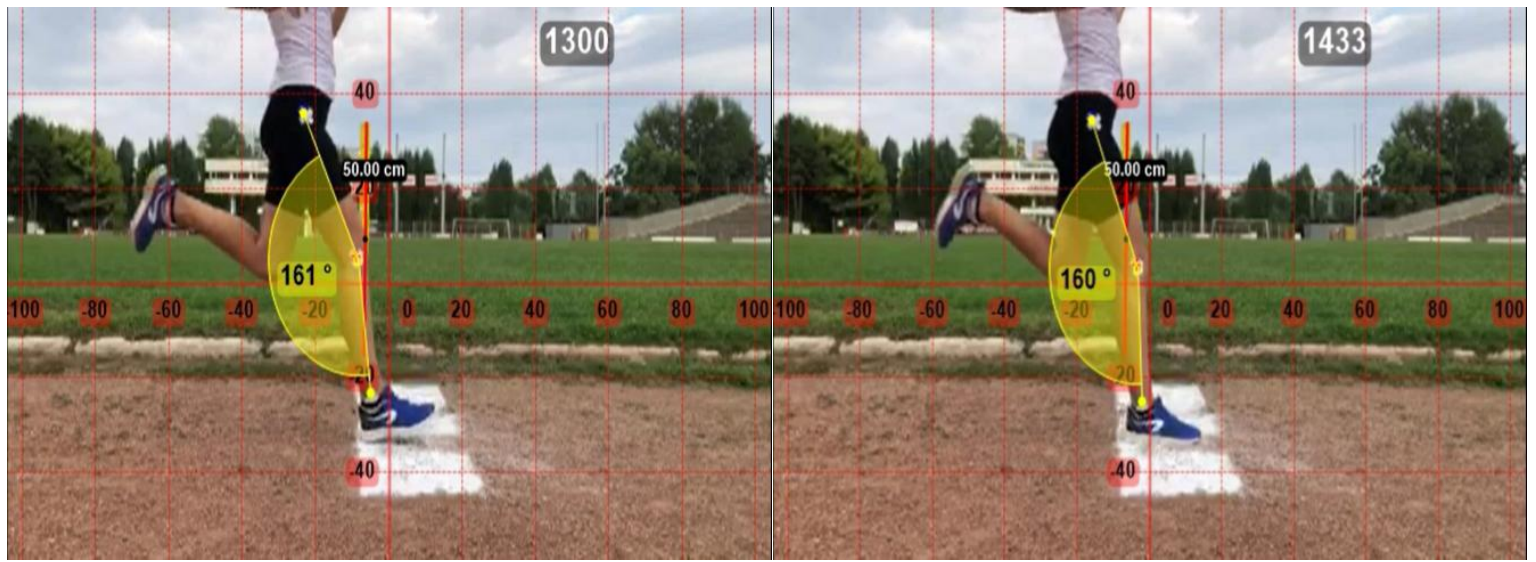

Runner no. 4 at the onset of the damping phase Runner no. 4 at the end of the damping phase

The damping phase of the runner no. 4 is identical as duration of the runner no. 3 , i.e. $133 \mathrm{~ms}$. The horizontal hip joint velocity decreases from $23.1 \mathrm{~m} / \mathrm{s}$ to $15.1 \mathrm{~m} / \mathrm{s}$. The knee joint is the same throughout the damping time, with a value of $54.1 \mathrm{~m} / \mathrm{s}$. The ankle joint velocity remains constant, but at $40.1 \mathrm{~m} / \mathrm{s}$. Thus, although the horizontal hip joint velocity decreases, the knee is stagnating throughout the damping phase, while it is advisable to decrease.

\section{Analysis of the push angle and thigh-calf angle in the push phase}

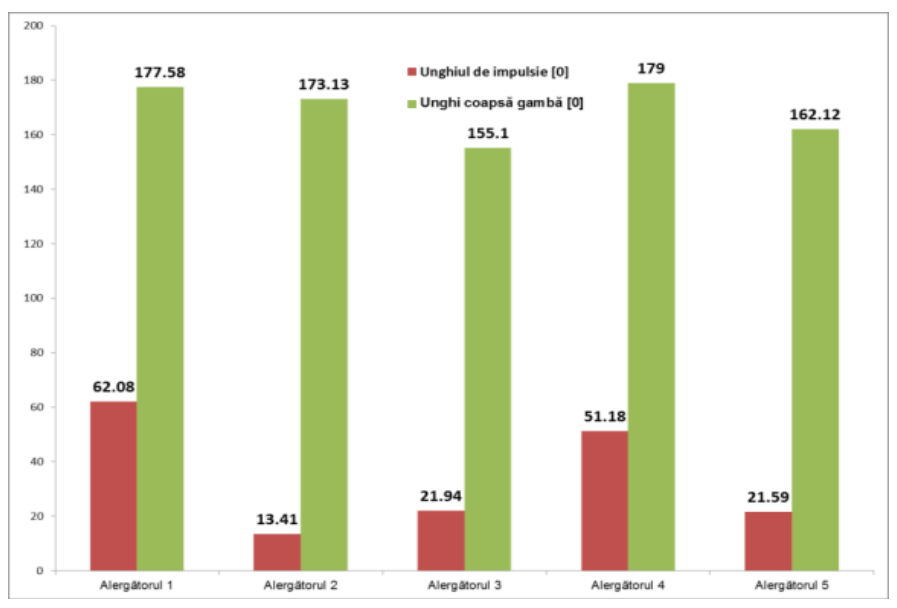

Figure 2 -Push angle and thigh-calf angle during impulse phase

The push phase starts when the vertical goes over and lasts until the foot falls off the ground. This phase is positive in the action of the support leg, being the active phase of the run, which can be influenced by reducing the push angle and / or increasing the push force (lower limb force).

$$
\alpha_{\text {push }}=\arctan \left(\frac{Z_{\text {hip }}-Z_{\text {knee }}}{\chi_{\text {ankle }}-\chi_{\text {knee }}}\right)
$$

We note that the push is the more effective as the push angle decreases. The data recorded in the
The angle of push can be considered as the angle that the thigh with the horizontal axis makes. For the participants in the research the push angle will be determined with the relation: preliminary experiment shows that this angle can be considerably reduced for each runner. 
Analysis of thigh-calf angle variation for each phase

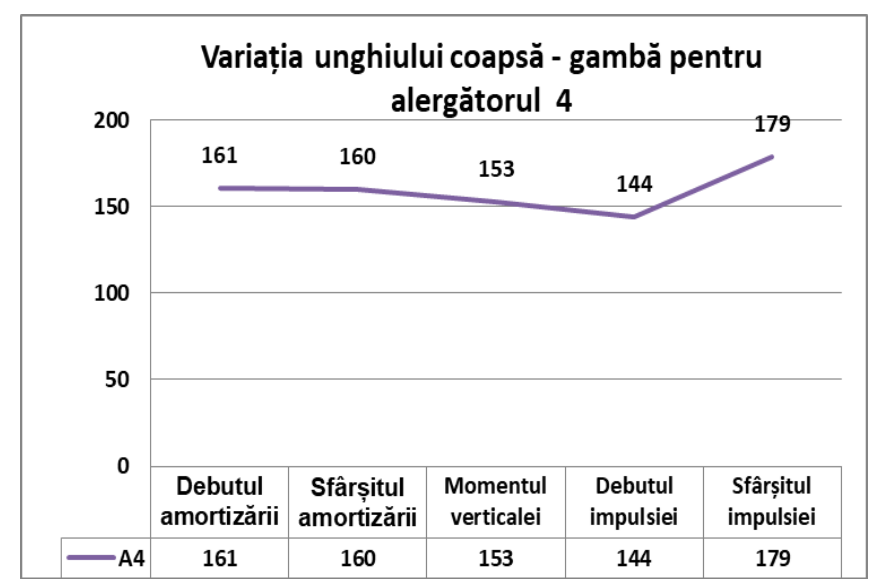

Figure 3 - Variation of thigh-calf angle during each phase for the runner 4

Damping takes place over $133 \mathrm{~ms}$. for the runner no. 4 , so that at the onset of the phase the thigh-calf angle measures $161^{\circ}$ and decreases one degree to the end of it. We are talking about the smallest decrease in the value of this angle from these two stages of damping so far.

From the end of the damping to the moment of the vertical, the angle decreases to $153^{\circ}$ and will continue to decrease, so at the onset of the push it is equal to $144^{\circ}$. The push takes place in $907 \mathrm{~ms}$. to this runner. Meanwhile, the thigh-calf angle value increases from $144^{\circ}$ to $179^{\circ}$.

In this case, the value of the thigh-calf angle does not vary greatly during damping and at the moment of vertical. Only at the start of the push phase there is a rapid increase of the angle in a shorter time interval than the three previously analyzed runners, as we have an active phase of the lower push (of only $907 \mathrm{~ms}$ ), while the push of the others runners lasted: $1100 \mathrm{~ms}, 1234 \mathrm{~ms}$. and 1167 ms.

\section{Conclusions from preliminary research}

We have concluded that:

- the contact with the ground denotes automatism and highlights many technical mistakes from the onset of damping.

- the duration of the contact with the ground can be improved by reducing damping and pulse time.

- the variation in the horizontal speed of the hip and knee joints in the damping phase of the runners participating in the experiment increases, rather than having a downward path. In this phase, the contact with the ground takes place. Ground response has a negative influence on running speed, hindering the continuity of running

At the moment of the impact with the ground, the lower segment bends and damps the shock, and the horizontal speed is reduced. In terms of horizontal speeds for the three joints, improvements can be made for all participants in the preliminary experiment.

\section{Recommendations following the preliminary investigation}

It is recommended that the athletes be monitored and evaluated constantly in order to observe the damping phase, the moment of the vertical and the pulse in the attempt to observe the duration of each phase, the contact with the ground, the impulse angle, the horizontal speeds of the three articulations studied: hip, knee, ankle.

Periodic use of kinematic records processed on Kinovea software is recommended, subject of study and analysis of the coach and the athlete in order to find solutions for optimizing and improving performance at this junior age.

\section{Selective References}

1. Bompa.T.O. - Teoria şi metodologia antrenamentului. Periodizare. (Training theory and methodology. Periodization), Ex Ponto, 2002. p.18.

2. Dragnea A. - Antrenamentul sportiv (Sports training) Editura Didactică și Pedagogică. București, 1990, p. 103.

3. Dragnea A. - Teoria și metodica dezvoltării calităților motrice (Theory and methodology of developing motor skills). Compendiu. M.T.S., București, 1991, p. 50.

4. Elwardany, S.H., El-Sayed, W.H. \& Ali, M.F., 2015. Reliability of Kinovea Computer Program in Measuring Cervical Range of Motion in Sagittal Plane. Open Access Library Journal, vol. 2, pp.1-10.

5. Epuran M. - Metodologia cercetării activităţilor corporale (Methodology of Body Activity Research ). Ediţia a II-a, Editura A.N.E.F.S., Bucureşti, 2005.

6. Epuran M. - Metodologia cercetării activităţilor corporale (Methodology of Body Activity Research),Editura A.N.E.F.S., vol. II, Bucureşti, 1992, p.395, p.295.

7. Guzmán-Valdivia, C.H., Blanco-Ortega, A., OliverSalazar, M.A.y CarreraEscobedo, J.L., 2013. Therapeutic Motion Analysis of Lower Limbs Using Kinovea. International Journal of Computing and Engineering, vol. 3, no. 2, pp.359-365

8. Manno R. - Les bases de l`entrainement sportif, MTSCCPPS-SDP 371-374, Bucuresti 1996, p.26.

9. Mereuță C., Atletism - Curs de bază (Athletics - Basic Course). 
10. Moldovan, E. - Aspecte cognitive şi de evaluare multicriterială în educaţia fizică şi sport (Cognitive and Multi-Criteria Assessment in Physical Education and Sports), Editura Universităţii Transilvania Braşov, Braşov, 2009 , p. 51

11. Navarro, E. - Facultad de Ciencias de la Actividad Física y del Deporte, Universida Politécnica De Madrid, International Conference of Physical Activity and Sport Sciences, 14-15 November, Cluj-Napoca, 2008.

12. Neamţu M., Ionescu B.I., Scurt C., Nechita Fl Atletismul pentru toţi (Athletics for all), Editura Universităţii Transilvania, Braşov, 2008, p.,121-138.
13. Nicu A. - Antrenamentul sportiv modern (Modern sports training), Editura Editis, Bucureşti, 1993, p.35

14. Pavelcu V., Didilescu I. - Logica(Logic, ediția a VI-a, Editura Didactică şi Pedagogică, Bucureti, 1967.

15. Tudor V. - Capacităţi condiţionale, coordinative şi intermediare - component ale capacităţii motrice (Conditional, coordinative and intermediate capacities component of the motor capacity), Editura R.A.I., Bucureşti, 1999, p.19-20, p.24. 